\title{
Relationships Between Physiological and Morphological Properties of Retinocollicular Axons in the Hamster
}

\author{
Richard D. Mooney and Robert W. Rhoades \\ Department of Anatomy, Medical College of Ohio, Toledo, Ohio 43699
}

\begin{abstract}
Intracellular recording and HRP injection were used to characterize retinocollicular axons in the hamster. Eighteen retinotectal axons were filled with HRP. The type of axon recovered most often $(N=10)$ had a receptive field with centersurround organization, gave sustained responses to flashed spots, had linear spatial summation, and responded only to more slowly moving stimuli. These fibers had a mean axonal diameter of $0.58 \mu \mathrm{m}(\mathrm{SD}=0.21)$ and an average conduction latency of $3.4 \mathrm{msec}(\mathrm{SD}=1.2)$ to optic chiasm (OX) stimulation. They gave rise to circular or vertically elongated arbors with an average cross-sectional area of $33,238 \mu \mathrm{m}^{2}$ (SD $=12,763)$ and were almost completely restricted to the stratum griseum superficiale (SGS). We recovered 6 fibers with very different structural and functional properties. The receptive fields of these axons also had center-surround organization, but gave phasic responses to flashed stimuli, had nonlinear spatial summation, and responded to rapidly moving stimuli. These axons had an average diameter of $0.84 \mu \mathrm{m}(\mathrm{SD}=0.09)$ and an average latency of $2.1 \mathrm{msec}$ (SD $=0.40$ ) to $O X$ stimulation. They had elongated arbors with an average cross-sectional area of $78,045 \mu \mathrm{m}^{2}(S D=14,252)$ and innervated the SGS, the stratum opticum (SO), and upper stratum griseum intermediale (SGl). We also recovered 2 fibers that had thin $(0.3$ and $0.6 \mu \mathrm{m})$ axons and latencies of 4.2 and $3.6 \mathrm{msec}$ to $\mathrm{OX}$ stimulation. They both gave rise to horizontally oriented arbors in the stratum zonale (SZ) and upper SGS.
\end{abstract}

One of the major advances in the study of the way in which the retina innervates the thalamus has been the application of intraaxonal recording and injection techniques to demonstrate the manner in which individual retinal axons arborize in their targets (e.g., Bowling and Michael, 1980, 1984; Sur and Sherman, 1982; Hamos et al., 1987; Sur et al., 1987; Michael, 1988; Roe et al., 1989). This approach has provided substantial information about the organization of the retinal projections to the dorsal lateral geniculate nucleus (LGNd) and medial interlaminar nucleus (see citations above), but with the exception of a single fiber illustrated by Bowling and Michael (1980), it has not been exploited to investigate the arborizations of retinal

\footnotetext{
Received Jan. 18, 1990; revised Apr. 23, 1990; accepted May 11, 1990

This work was supported in part by NIH Grants EY 04170 and EY 08015, NSF Grant BNS 85-00142, a grant from the Ohio Lions Club, and funds from the State of Ohio Research Challenge. We wish to thank Paul R. Hess, Zebetta King, Anne C. Lewin, Todd King, J. Bradley Burns, and John Clements for excellent technical assistance.

Correspondence should be addressed to Dr. Richard D. Mooney, Department of Anatomy, Medical College of Ohio, CS \# 10008, Toledo, OH 43699.

Copyright (C) 1990 Society for Neuroscience $0270-6474 / 90 / 093164-14 \$ 03.00 / 0$
}

fibers in their other major subcortical target, the superior colliculus (SC).

Both electrophysiological and neuroanatomical experiments have established that multiple retinal cell types send axons to the SC in the monkey (Bunt et al., 1975; Schiller and Malpeli, 1977; Marrocco, 1978; Leventhal et al., 1981; Perry and Cowey, 1984), cat (Hoffmann, 1973; Fukuda and Stone, 1974; Kelly and Gilbert, 1975; Magalhaes-Castro et al., 1976; Mcllwain, 1978; Wässle and Illing, 1980; Itoh et al., 1981; Leventhal et al., 1985), and rodent (Fukuda et al., 1978; Chalupa and Thompson, 1980; Linden and Perry, 1983; Hofbauer and Dräger, 1985).

Retrograde tracing and physiological studies in both the cat (Hoffmann, 1973; McIlwain, 1978; Itoh et al., 1981) and the rodent (Fukuda et al., 1978; Hofbauer and Dräger, 1985) have further shown that different classes of retinal ganglion axons almost certainly terminate in different SC sublaminae. These studies have demonstrated that large retinal ganglion cells with rapidly conducting axons innervate the ventral portion of the superficial laminae [the superficial SC laminae consist of the stratum zonale (SZ), stratum griseum superficiale (SGS), and stratum opticum (SO)], while smaller ganglion cells with more slowly conducting axons terminate in more dorsal portions of these layers. In the cat, the available evidence suggests strongly that W-type axons terminate in the SZ and uppermost SGS, while $Y$ axons terminate in the lower SGS, SO, and perhaps the upper portion of the stratum griseum intermediale (SGI; Hoffmann, 1973; Mcllwain, 1978; Berson and Mcllwain, 1982; Beckstead and Frankfurter, 1983). As yet, however, none of these conclusions have been confirmed by analysis of individual axons that have been characterized both physiologically and anatomically.

The aim of the experiment reported in this paper was to use intraaxonal recording and HRP injection techniques to characterize the retinal ganglion cell axons that innervate the $\mathrm{SC}$ in the hamster.

\section{Materials and Methods}

Our methods for recording, tissue processing, and analysis have been described in detail in earlier papers (e.g., Mooney et al., 1985; Rhoades et al., 1987) and will be presented only briefly here.

Animal preparation. The data reported were obtained from 61 adult (3-12 months old) hamsters of both sexes. Each hamster was anesthetized with sodium pentobarbital $(60 \mathrm{mg} / \mathrm{kg}$, i.p., with $0.1 \mathrm{ml}$ atropine sulfate in $1.5 \%$ solution). The trachea was cannulated and heart-rate recording leads were fastened to the skin of the chest. The hamster was then placed in a stereotaxic apparatus that left the visual field unobstructed. A puncture was made in the cisterna magna, and the skull and the dura overlaying the $\mathrm{SC}$ and posterior thalamus was removed, as was a small piece of skull over the optic chiasm (OX) and optic nerve. The eyelids were retracted, and the corneas were kept moist with a solution of polyvinyl alcohol (Liquifilm Tears). All wound edges were 


\section{A}
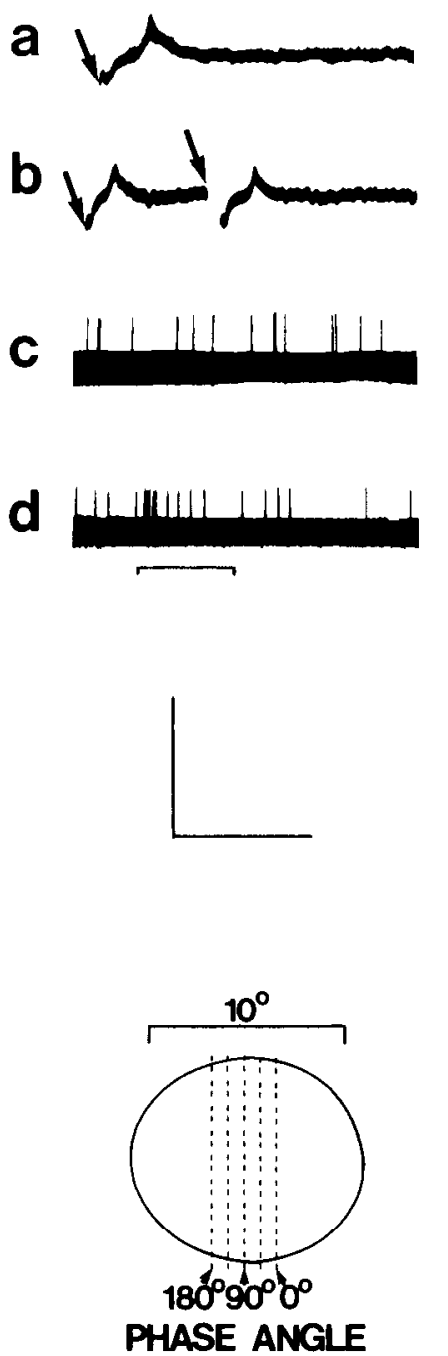
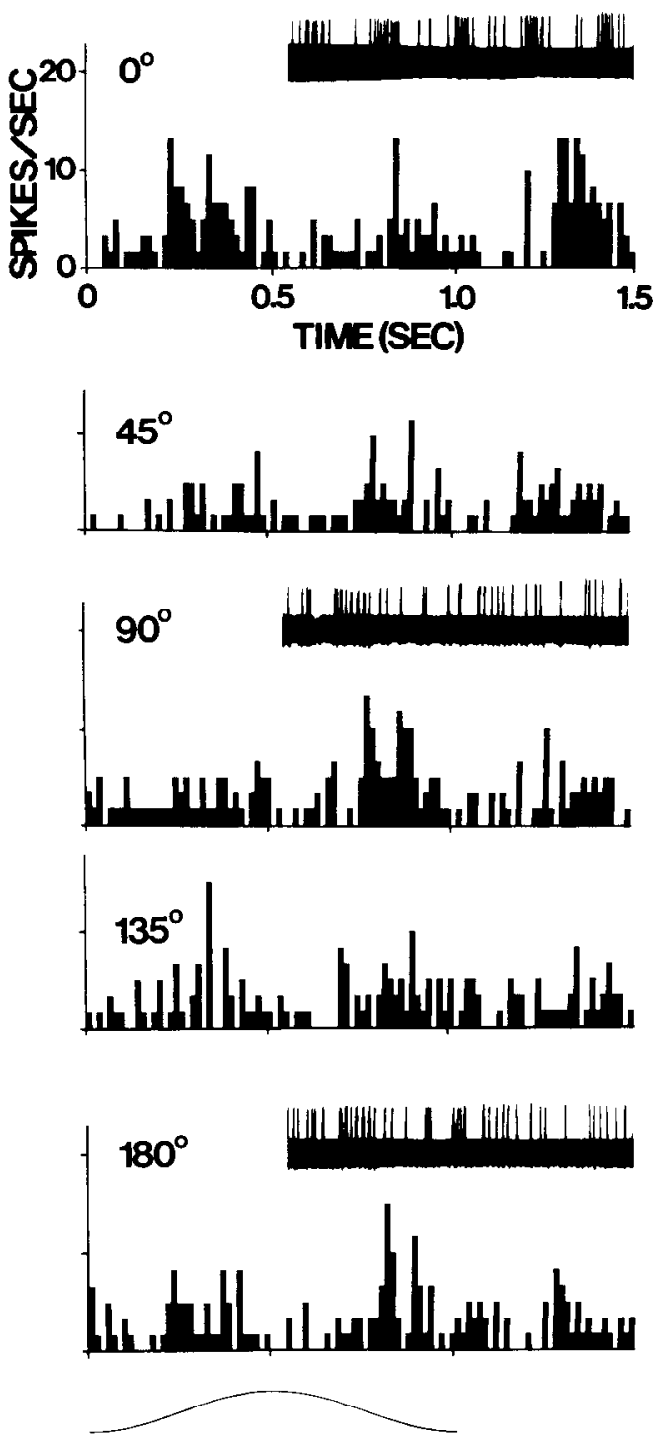
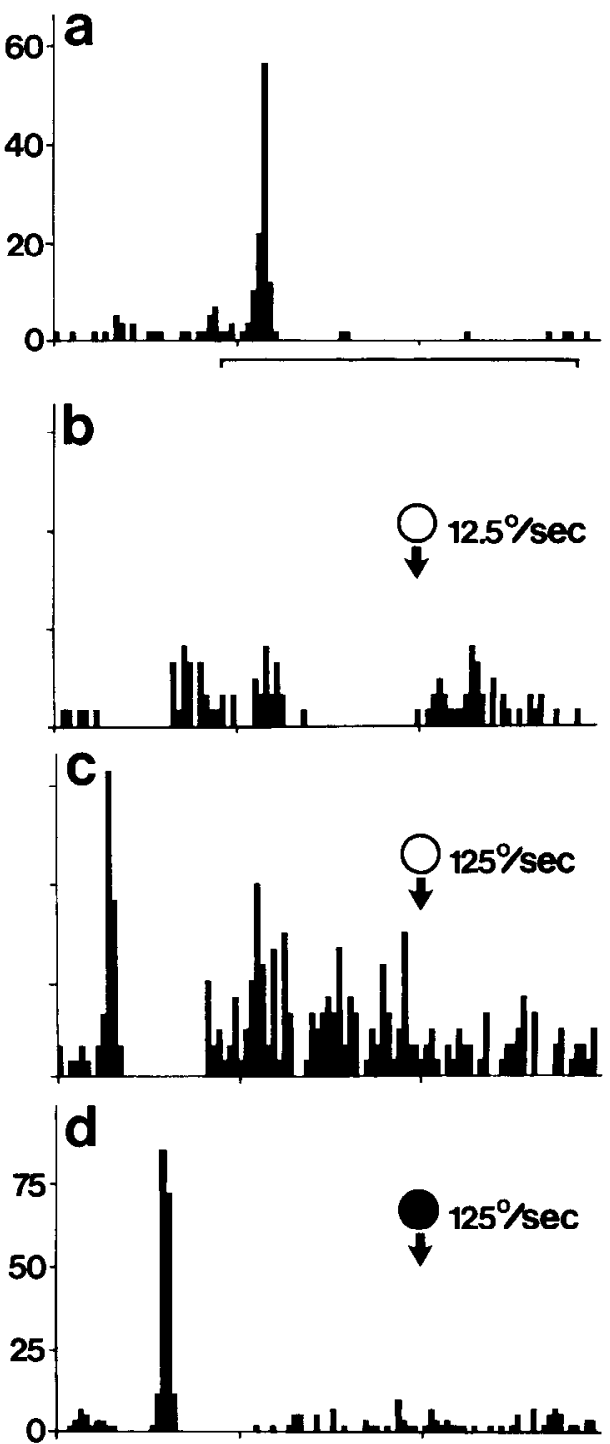

Figure 1. Physiology for on-center Type 1 fiber recorded in SC. $A$, Responses to single $(a)$ and double $(b)$ electrical stimulation of the OX (arrows indicate occurrences), spontaneous activity $(c)$, and the response to a spot positioned in the receptive field ( $d$, underline denotes flash duration). $B$, Tests for spatial summation. Responses to counterphase grating stimulation are shown as PSTHs to 1.5 temporal cycles (sine wave below PSTUs) and as spike traces (insets) to 2 cycles. The grating was presented at 5 spatial phase angles (see receptive-field plot). The responses show frequency doubling and lack of null position. $C$. PSTHs to a flashed stationary spot ( $a$, flash duration indicated by underline), to a white spot moving through the receptive field at 12.5 and $125 \% \mathrm{sec}(b, c)$ and to a black spot moving $125 \% \mathrm{sec}(d)$. The calibration in $A$ (at bottom) is $20 \mathrm{mV}$ and $4 \mathrm{msec}(a, b)$ or $2 \sec (c, d)$; this also applies to the traces in $B$. The time base for all PSTHs is $1.5 \mathrm{sec}$.

infiltrated with a long-lasting local anesthetic (nupercaine, CIBA), and at least $1 \mathrm{hr}$ prior to recording, urethane $(1.2 \mathrm{~g} / \mathrm{kg}$ in distilled water, i.p.) was substituted for the pentobarbital anesthesia. The hamster was then paralyzed with $10 \mathrm{mg}$ gallamine triethiodide (i.p.), and artificial respiration was carried out according to values of Freminet et al. (1972). Anesthesia and paralysis were maintained with hourly doses of urethane and gallamine triethiodide ( $30 \mathrm{mg}$ and $4 \mathrm{mg}$, respectively). Body temperature was held at $37 \pm 1^{\circ}$ with a heating blanket controlled by feedback from a rectal monitoring probe.

We verified that our anesthetic regimen was effective by employing it in hamsters that were unparalyzed. Such animals lie quietly and are behaviorally unresponsive to external stimuli for at least $1 \mathrm{hr}$ after discontinuance of urethane. We have also allowed hamsters to recover from paralysis during the course of recording experiments and determined that anesthesia was still sufficient to prevent responses to any mechanical stimulation, including pinch with a pair of serrated forceps.

The pupils were not dilated in these experiments, and the natural pupil size during recording was $0.8-1.5 \mathrm{~mm}$. Auxiliary lenses were not used to refract the eyes because of the relatively large depth of focus previously found in the small eyes of rodents (Powers and Green, 1978). At the conclusion of each experiment, the pupils were dilated with $1.5 \%$ homatropine hydrobromide, and the position of the optic nerve head was back projected through an opthalmoscope onto the tangent screen (Fernald and Chase, 1971). This landmark served as a reference for relating the receptive-field positions to the "area centralis" as defined by Tiao and Blakemore (1976). We have verified that plotting the optic disk only at the end of the recording session is sufficient to cstablish its location for the entire duration of the experiment in paralyzed hamsters. This verification is from previous studies in which the optic disk location was mapped multiple times during the course of recording (e.g., Mooney et al., 1987).

Recording, electrical stimulation, and HRP injection. Optic axons were recorded in the SC with micropipettes that were pulled from Starbore tubing (Radnotti Glass Technology) and beveled after filling to 

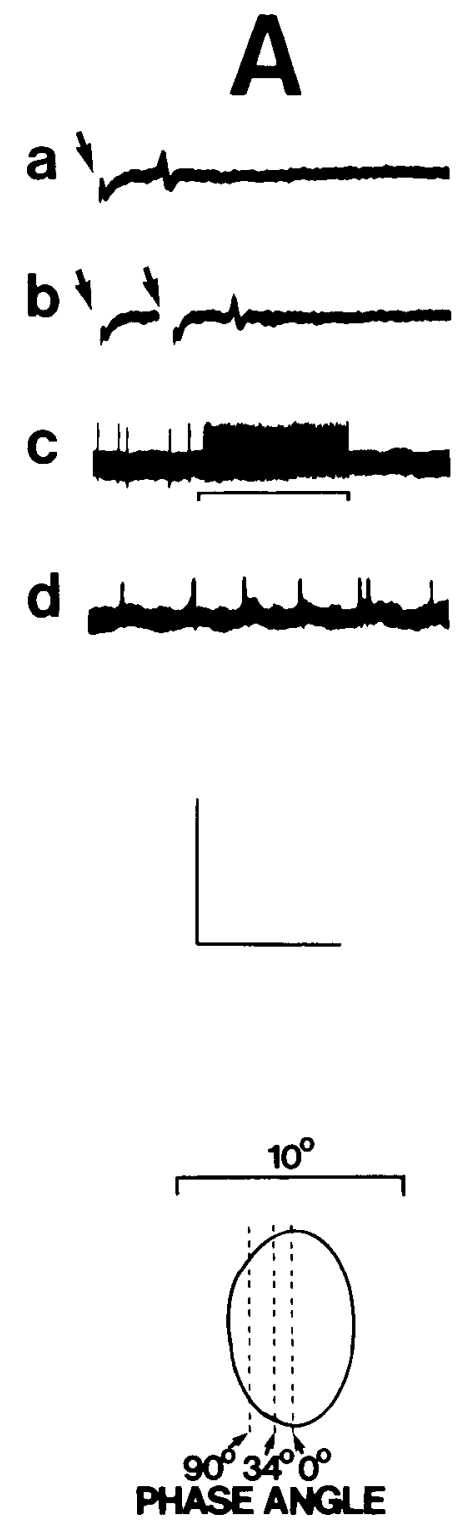

Figure 2. Visual and electrically evoked responses from on-center Type 2 fiber recorded in SC. Conventions are the same as those in Figure 1. $A$, Responses to single $(a)$ and double $(b)$ OX stimulation (arrows) and the response to a maintained spot (underline) in the receptive-field center $(c)$ and spontaneous activity $(d)$. $B$, Singlc oscilloscope traces and PSTHs in response to counterphase presentation of a spatial sine-wave grating $\left(0.13\right.$ cycles $\left.^{\circ}\right)$ with sinusoidal temporal modulation (1.06 $\mathrm{Hz}$, time course shown below PSTHs). The position of the grating with respect to the receptive field is shown for 3 spatial phase angles. Note that at $0^{\circ}$, no modulated response was evoked, which indicates linear spatial summation. The calibration in $A$ is $20 \mathrm{mV}$ and $4 \mathrm{msec}$ $(a, b)$ or $2 \sec (c, d)$; this also applies to the traces in $B$.
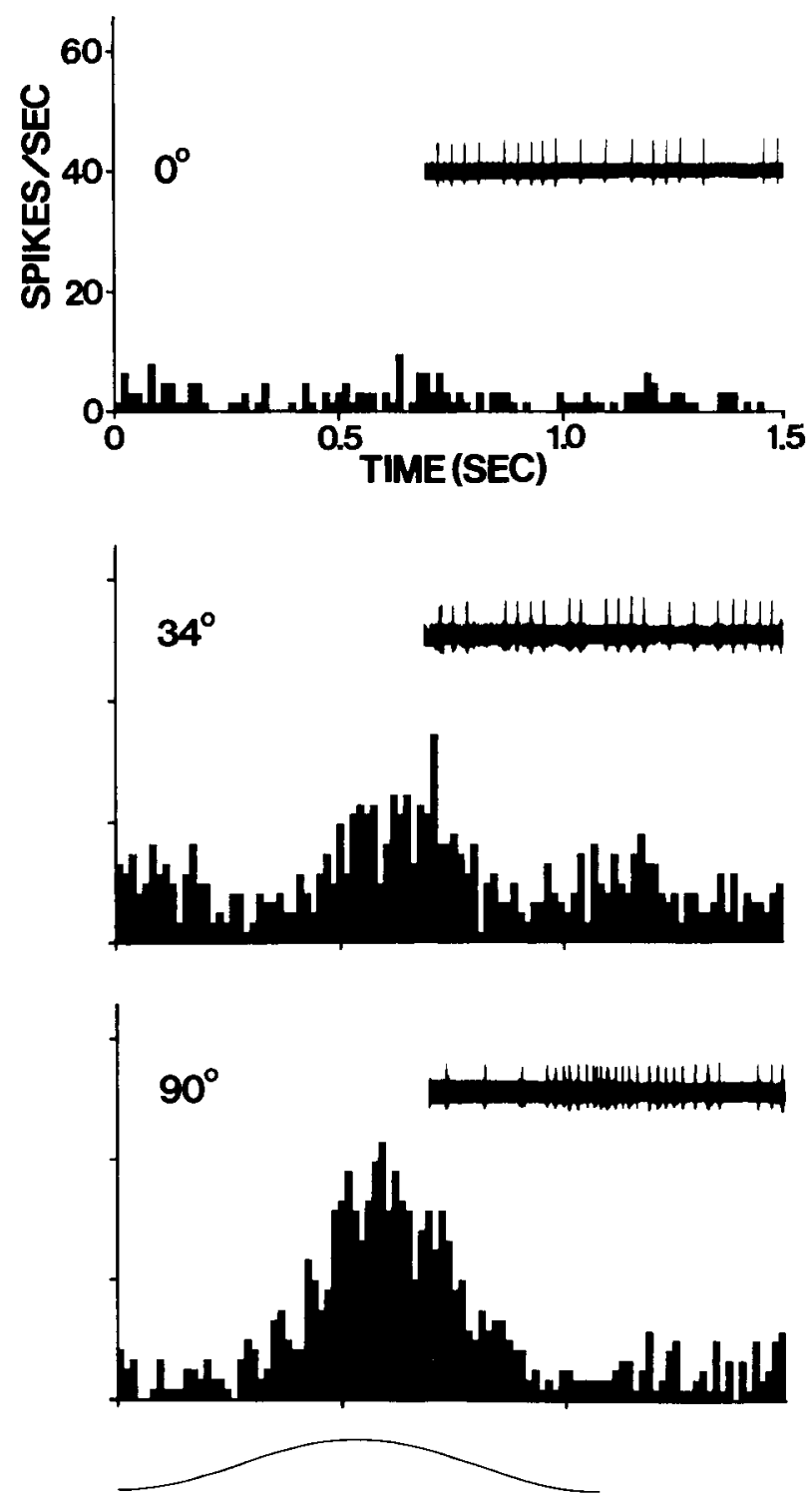

resistances of $80-120 \mathrm{M} \Omega$ (tip size, $<0.6 \mu \mathrm{m}$ ). These were filled with a solution of $6 \%$ HRP (Sigma, type VI), $0.05 \mathrm{~m}$ Tris buffer $(\mathrm{pH}, 8.3$ ), and $0.3 \mathrm{M} \mathrm{KCl}$. Signals from these electrodes were recorded on an amplifier (Eutectic Electronics, model 400A) and displayed on a storage oscilloscope and audio monitor. Individual spikes were converted to pulses by a window discriminator and counted into peristimulus time histograms (PSTHs) by computer (1401 interface, Cambridge Electronic Design, Ltd.). All responses were evaluated in detail extracellularly and defining properties were rechecked after impalement of the fiber.

An impalement was indicated by a sudden drop in DC potential of $5 \mathrm{mV}$ or more together with an increase in spike amplitude of $5-40$ $\mathrm{mV}$. Iontophoresis of HRP into the axon was accomplished with 2-3nA pulses of $250 \mathrm{msec}$ duration at $1.8 \mathrm{~Hz}$ for $1-2 \mathrm{~min}$.

Concentric bipolar stimulating elcctrodes were positioncd in the $\mathrm{OX}$ or in the optic nerve up to $1.0 \mathrm{~mm}$ from the OX. The location of the stimulating electrode in each experiment was verified histologically. Search stimuli of $250 \mu \mathrm{A}$ in amplitude and $75 \mu \mathrm{sec}$ in duration were typically used to locate optic axons (thresholds for fibers ranged from $10-130 \mu \mathrm{A}$ with a mean of $62 \mu \mathrm{A}$; there was no correspondence between fiber class and threshold current).

Identification of fibers. Axons were first identified by examining their responses to stimulation of the $\mathrm{OX}$. The axons could be distinguished from SC cells as follows: (1) their latency to each stimulus in $10-\mathrm{Hz}$ trains varied by not more than $0.1 \mathrm{msec}$, and (2) the individual spikes produced by trains of 3 pulses with $2 \mathrm{msec}$ separation did not vary in their latencies by more than $0.1 \mathrm{msec}$ from one trial to the next. Cells of the SC, as judged by the resultant intracellular HRP recoveries (Mooney et al., 1985) and by synaptic blockade of their responses with local injections of cobaltous chloride (R. D. Mooney and R. W. Rhoades, unpublished observations), never met either of these criteria.

Sensory stimulation. Visual stimuli were presented on a tangent screen (background luminance, $1 \mathrm{~cd} / \mathrm{m}^{2}$ ) either by means of back projecting bright spots or bars (maximum luminance, $38 \mathrm{~cd} / \mathrm{m}^{2}$ ) or by moving handheld dark spots (luminance, $0.14 \mathrm{~cd} / \mathrm{m}^{2}$ ) in front of the screen, with or without simultaneous back projection. Receptive fields were plotted on the screen using a flashed spot $0.3^{\circ}$ in diameter. The locations of regions where on, off, or on-off discharges were evoked was judged by listening to the audio monitor, and these areas were drawn on the screen. Weak concentric surrounds were studied by masking the center and flashing a full or partial annulus. Purely suppressive or silent surrounds (as opposed to antagonistic concentric surrounds) were indicated by a decrement in the excitatory center response when both center and sur- 
round were stimulated simultaneously. The distance from the tangent screen to the eye was measured for each plotted receptive field and ranged from 15 to $25 \mathrm{~cm}$.

Axons were also tested with stimuli produced on a cathode-ray screen (Innisfree, Cambridge, MA; background luminance of the screen, 1.1 $\mathrm{cd} / \mathrm{m}^{2} ;$ maximum luminance, $15 \mathrm{~cd} / \mathrm{m}^{2}$ ).

Receptive field tests and classification of optic fibers. Receptive field tests using either hand-held or back-projected stimuli were adapted from those used by Cleland, Levick, and their collaborators (Cleland et al., 1971, 1973; Cleland and Levick, 1974a, b, 1975) and also from Stone and Fukuda (1974). The response properties we evaluated included the time course of the response to a standing stimulus, the response to rapid movement through the receptive field of a large-diameter spot that was opposite in contrast to the center type, the response to rapidly alternating contrast, the response to slowly moving, high-contrast square-wave gratings $\left(0.1,0.2\right.$, and 0.4 cycles $\left./{ }^{\circ}\right)$, and responses or lack thereof to phase transition of a bipartite field placed at differed locations within the receptive field (Kratz et al., 1978).

The cathode-ray screen system was used to assay velocity sensitivity and directional selectivity to moving spots. We also used this system to evaluate responses to both drifting and counterphase sine-wave gratings (typically set at $80 \%$ contrast, $0.13-0.25 \mathrm{cycles} /{ }^{\circ}$, sinusoidally modulated at $1 \mathrm{~Hz}$ alternation), in order to determine linearity or nonlinearity of spatial summation.

Perfusion, tissue processing, and reconstruction of axon arbors. No more than $8 \mathrm{hr}$ after the first attempted injection, hamsters were perfused transcardially according to the method described by Mooney et al. (1985). After $12-60 \mathrm{hr}$ of postfixation, the brain was removed, and 1 block containing the $\mathrm{SC}$ and caudal thalamus and a second containing the OX and attached optic nerve were removed from it. The block containing the SC was sectioned at $100 \mu \mathrm{m}$ and processed for the demonstration of diaminobenzidine (DAB) reaction product according to the protocol described by Semba et al. (1983). Tissue was then plated from a $2 \%$ gelatin solution onto subbed slides, air dried, dehydrated in absolute ethanol, cleared in xylene, and coverslipped. The block containing the $\mathrm{OX}$ was sectioned at 60 or $100 \mu \mathrm{m}$ and stained with thionin to localize the position of the stimulating electrode.

All axons were reconstructed on a Nikon Optiphot microscope at a total magnification of $720 \times$, using a $40 \times$ planapochromatic objective and drawing tube. All reconstructions were in the coronal plane and the cross-sectional areas of axon arbors were determined by enclosing all bouton-like swellings within a single contour. Bouton and parent axon diameters were measured with a calibrated eyepiece reticle, using a $100 \times$ oil immersion objective. Laminar boundaries of the SC were identified, in most instances, by viewing the sections with dark-field optics and lower-power objectives and, in some cases, by removing the coverslips and counterstaining the sections with thionin.

Statistical analysis. Unless otherwise noted, all statistical comparisons between the different classes of retinal axons that we recovered were made by means of independent $t$-tests. This approach is justified because we never recovered more than 1 retinal axon from a given hamster.

\section{Results}

Morphological data were obtained from 18 functionally characterized retinal axons. Seventeen were recovered in the SC, and 1 terminated mainly in the nucleus of the optic tract.

\section{Physiological properties of recovered axons}

All but 2 of the axons we recovered could be categorized into 1 of 2 groups (Type 1 or Type 2) on the basis of their latency to electrical stimulation and at least 2 receptive-field tests.

Type 1 axons had antagonistic center-surround receptive fields and were distinguished by short latencies to electrical stimulation of the OX; no decrement in response strength (number of spikes) to a spot moving at $100 \% \mathrm{sec}$ as compared to one moving $10 \%$ sec, strong modulation of firing by only the $0.1 \mathrm{cycle}^{\circ} \mathrm{square}-$ wave grating with a weak or, more often, no modulatory response to the higher spatial frequency gratings; phasic response (i.e., return to within $25 \%$ spontaneous level of firing $2 \mathrm{sec}$ after presenting a fixed spot to the receptive field center); and continuous discharge to a rapidly alternating bright/dark spot.

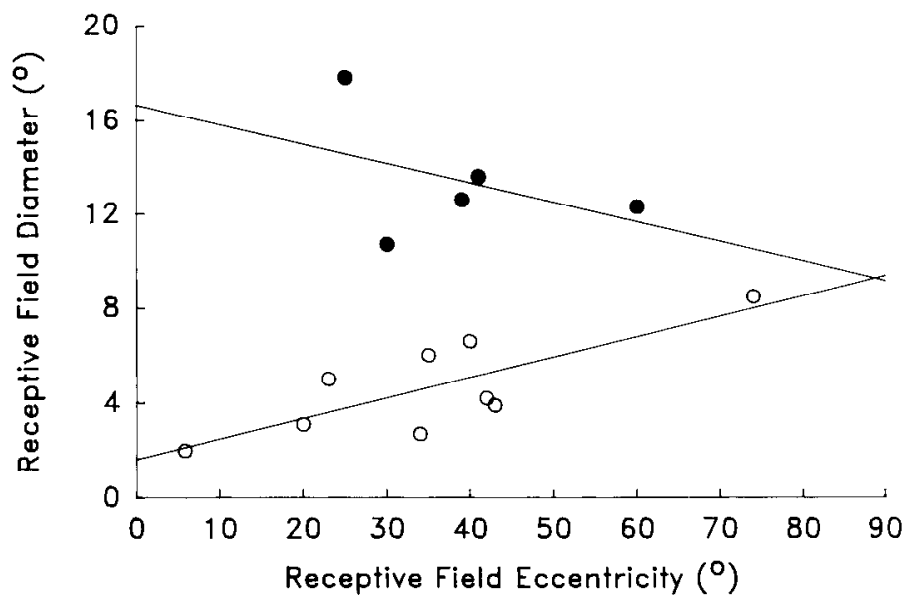

Figure 3. Scatterplots relating receptive-field size and eccentricity for recovered Type 1 (solid circles) and Type 2 (open circles) retinotectal axons. There was no significant correlation between receptive-field center diameter and receptive-field eccentricity for Type 1 axons $(r=-0.42$, $p>0.05)$, but there was for the Type 2 fibers $(r=0.79, p<0.05)$.

Figure 1 shows records from a Type 1 fiber. This axon responded to OX stimulation with a latency of $2.05 \mathrm{msec}$ (Fig. 1, $A, \mathrm{a}, \mathrm{b})$. It demonstrated frequency doubling and the lack of a null position when its receptive field was stimulated with counterphase sinusoidal gratings at different phase angles (Fig. $1 B$ ). It gave a phasic response to a sustained stationary spot placed over the receptive-field center (Fig. $1 C$, a) and responded vigorously to rapidly moving stimuli (Fig. $1 C, \mathrm{c}, \mathrm{d}$ ).

Type 2 axons had receptive fields with partial or complete antagonistic center-surround organization and gave sustained responses to flashed stimuli. These fibers responded well to moderate stimulus velocities $(<50 \% / \mathrm{sec})$ and poorly to velocities $>100 \%$ sec. The firing of these axons was invariably modulated by the 0.2 cycle $^{\circ}$ grating and usually also by the 0.4 cycle $^{/ \circ}$ grating. These fibers generally had smaller receptive fields and longer latencies to OX stimulation than Type 1 axons.

Figure 2 illustrates data from a Type 2 fiber. It responded to OX stimulation with a latency of $3.2 \mathrm{msec}$ (Fig. $2 A$, a, b). It gave a sustained response to a spot illuminating the receptive field center (Fig. $2 A$, c). Stimulation using a counterphase grating (Fig. $2 B$ ) demonstrated a clear "null" position (Fig. $2 B$, top PSTH) indicative of linear spatial summation (Enroth-Cugell and Robson, 1966).

Although spatial linearity was not used to classify every retinal axon, 4 Type 1 and 3 Type 2 fibers were held long enough to obtain data at 3 or more positions in the receptive field with the counterphase sine-wave grating. A null test was used to evaluate the linearity of spatial summation (Enroth-Cugell and Robson, 1966; Hochstein and Shapley, 1976). All Type 1 axons gave responses at all spatial phase angles to the counterphase grating and showed no consistent position dependence. These axons responded to the temporal modulation at twice the fundamental stimulus frequency and showed a temporal phase advance at $1 \mathrm{~Hz}$. The 3 Type 2 fibers had an identifiable null position, and all of them showed sinusoidal temporal modulation that followed the stimulus. Two incompletely tested Type 2 axons showed sinusoidal temporal modulations, and their response magnitudes were dependent upon the spatial phase angle. Two additional incompletely tested Type 2 axons gave 


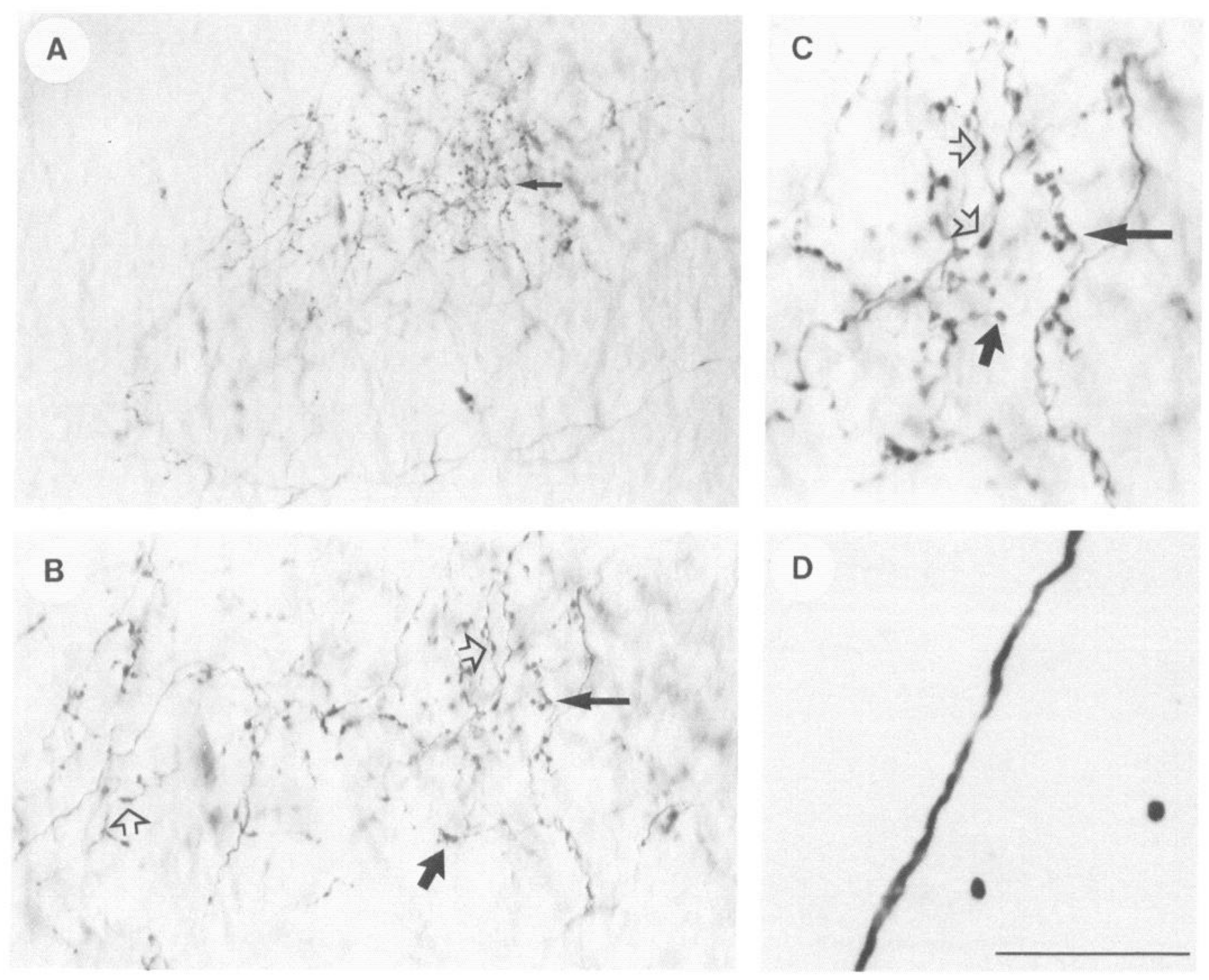

Figure 4. Photomicrographs showing morphology of Type 1 axon reconstructed in Figure 5. A, Low-power photomicrograph that depicts the central portion of the fiber's terminal arbor. The arrow denotes the point that is also indicated by the long, solid arrows in $B$ and $C$. $B$ and $C$, Higher-power photomicrographs that show portions of the same arbor. The open arrows point to boutons en passant and the short, solid arrows point to clusters of terminal boutons. $D$, The parent fiber in the SO. Scale bar: $100 \mu \mathrm{m}$ for $A, 50 \mu \mathrm{m}$ for $B, 30 \mu \mathrm{m}$ for $C, 15 \mu \mathrm{m}$ for $D$.

"silent substitutions" using the bipartite field stimulus, which is also indicative of linear spatial summation (Enroth-Cugell and Robson, 1966; Kratz et al., 1978).

The average conduction latency for the Type 1 axons was 2.1 $\mathrm{msec}(\mathrm{SD}=0.40)$, and that for the Type 2 fibers was $3.4 \mathrm{msec}$ $(\mathrm{SD}=1.2)$. This difference was statistically significant $(p<0.05)$. There were also substantial differences in the receptive-field sizes of Type 1 and Type 2 retinal axons. The average receptivefield center diameter for the Type 1 axons was $13.4^{\circ}(\mathrm{SD}=2.7)$, and that for the Type 2 fibers was $4.7^{\circ}(\mathrm{SD}=2.1)$. This difference was also statistically significant $(p<0.001)$. There was no significant correlation between receptive-field center diameter and receptive-field eccentricity for Type 1 axons $(r=-0.42, p>$ $0.05)$, but there was for the Type 2 fibers $(r=0.79, p<0.05$; Fig. 3).

\section{Morphological properties of Type 1 and Type 2 axons}

Both qualitative and quantitative analysis demonstrated that the Type 1 and Type 2 fibers we recovered in the hamster SC were morphologically distinct.

Type 1 axons $(\mathrm{N}=6)$

The morphological properties of typical Type 1 fibers from the hamster SC are illustrated in Figures 4-6. These axons entered the $\mathrm{SC}$ in the brachium (e.g., Figs. $4 D, 6 C$ ), divided into major branches in the SO (Fig. 4,B,C), then traveled to their terminal fields in the SO and SGS. The Type 1 axons we recovered generally had arbors that were angled from lateral to medial and, with rare exceptions (e.g., Fig. $6 D$ ), they gave off a substantial number of boutons in the SO. Five of the 6 Type 1 
axons we recovered (including the fiber that terminated mainly in the nucleus of the optic tract) also had at least some portion of their terminal arbors in the SGI. When Type 1 axons terminated, they gave rise to both en passant (Fig. $4 C$, open arrows) and terminal (solid arrows) boutons.

Type 2 axons $(\mathrm{N}=10)$

The morphological characteristics of typical Typc 2 axons arc shown in Figures 7-9. All of these fibers entered the SC through the brachium (e.g., Fig. $7 B$ ). Upon reaching their targets, fibers in this class generally turned dorsally and gave rise to circular arbors or arbors that were elongated in the dorsoventral axis. The terminal arbors of Type 2 fibers were almost completely restricted to the middle portion of the SGS and, upon terminating, these axons gave rise to both en passant (Fig. $7 D$, open arrows) and terminal (solid arrow) boutons. Several Type 2 axons (e.g., Figs. 7; 9, $E, G, H$ ) gave off a few collaterals in the $\mathrm{SO}$, but these arborizations were quite minor relative to the terminations in the SGS. None of the Type 2 axons that we recovered had terminal arbors extending either to the SC surface or into the SGI.

Quantitative comparison of morphological characteristics of Type 1 and Type 2 retinal axons and relationships hetween structure and function

The differences between the morphological characteristics of retinotectal Type 1 and Type 2 axons illustrated in Figures 49 were generally statistically significant. The cross-sectional areas in the coronal plane of Type 1 axons were larger than those of Type 2 fibers. The mean cross-sectional area for the Type 1 axons was $78,045 \mu \mathrm{m}^{2}(\mathrm{SD}=14,252)$, and that for the Type 2 fibers was $33,238 \mu \mathrm{m}^{2}(\mathrm{SD}=12,763, p<0.001)$. Surprisingly, given the large difference between their arbor areas, there was no significant difference between the average number of boutonlike swellings for the 2 classes of retinal axons. The Type 1 axons gave rise to an average of $398(\mathrm{SD}=234)$ boutons, and the Type 2 fibers gave rise to an average of 382 boutons $(\mathrm{SD}=189$, $p>0.05$ ). As a result of this similarity in bouton number and the difference in arbor area, the bouton density for Type 2 fibers was significantly higher than that for Typc 1 axons $(p<0.05)$.

There was also a significant difference between the laminar distributions of both terminal arbors and boutons for the Type 1 and Type 2 fibers. The Type 2 fibers had $96 \%(\mathrm{SD}=2.5$ ) of their terminal arbors in the SGS and $4 \%(\mathrm{SD}=2.5)$ in the SO. None of the Type 2 axons arborized in the SGI. The Type 1 fibers had $42 \%(S D=22)$ of their terminal arbors in the SGS, $35 \%(\mathrm{SD}=17)$ in the SO, and $23 \%(\mathrm{SD}=15)$ in the SGI. This difference between the terminal arbors of Type 1 and Type 2 retinotectal axons was statistically significant $\left(\chi^{2}=68, d f=2\right.$, $p<0.001$ ).

The laminar distributions of bouton-like swellings for the Type 1 and Type 2 axons matched the distributions of their arbors. The Type 2 fibers had $98.5 \%(\mathrm{SD}=3.0)$ of their boutons in the SGS and $1.5 \%(\mathrm{SD}=3.0)$ in the SO. The Type 1 fibers had $51.2 \%$ ( $\mathrm{SD}=25.1$ ) of their boutons in the SGS, 32.2\% (SD $=26.2)$ in the SO, and $16.6 \%(\mathrm{SD}=23.8)$ in the SGI. This difference between the Type 1 and Type 2 fibers was statistically significant $\left(\chi^{2}=58, d f=2, p<0.001\right)$. There was no difference between the size of the bouton-like swellings measured from Type 1 and Type 2 fibers (Fig. 10).

The average axon diameter for Type 1 fibers was $0.84 \mu \mathrm{m}$ $(\mathrm{SD}=0.09)$, and that for Type 2 axons was $0.58 \mu \mathrm{m}(\mathrm{SD}=$

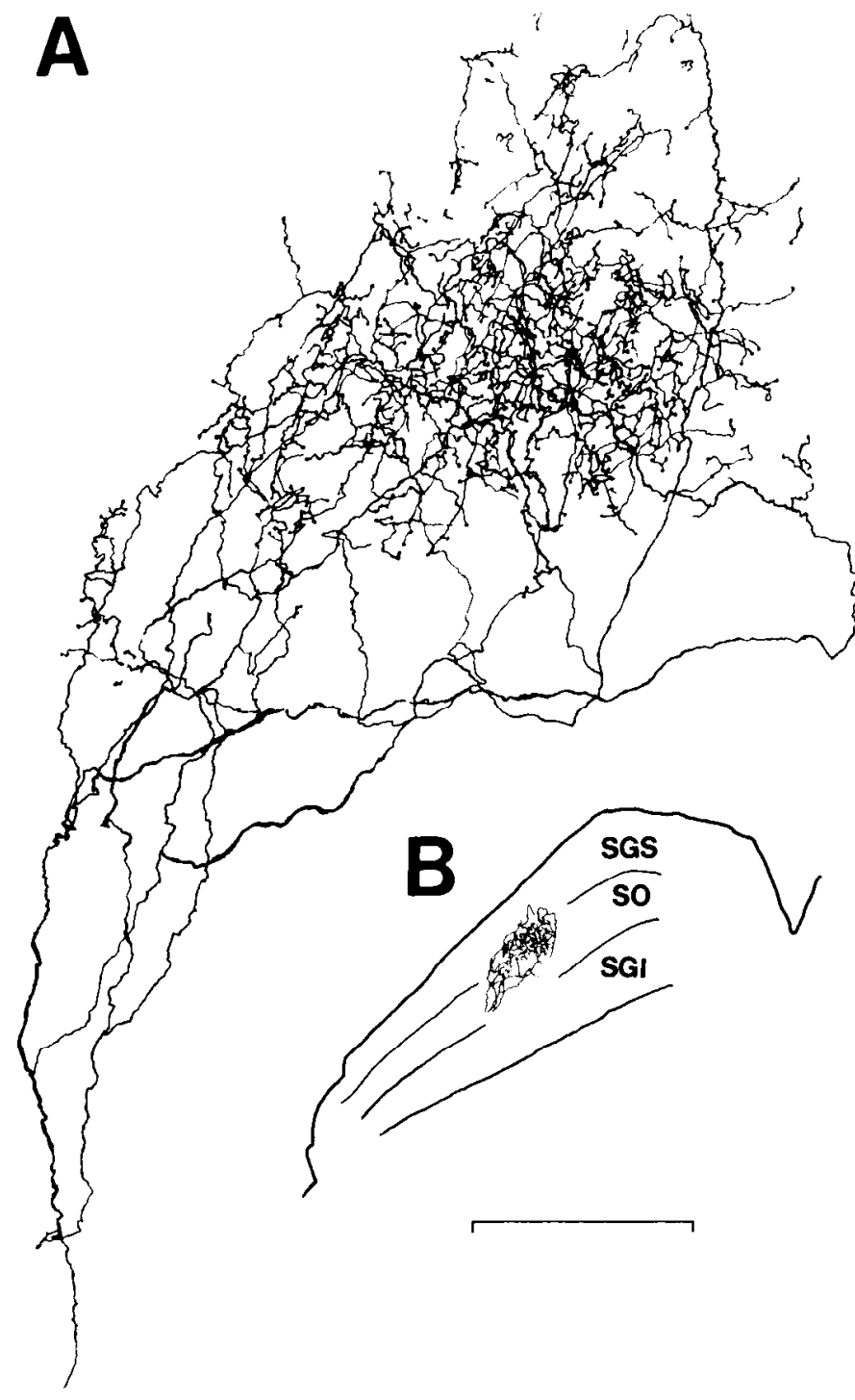

Figure 5. High and low power reconstructions for the Type 1 axon depicted in Figure 4. Scale bar: $100 \mu \mathrm{m}$ for $A, 1 \mathrm{~mm}$ for $B$.

$0.21)$. This difference was statistically significant $(p<0.050)$, and there was also a strong correlation between conduction latency and axon diameter for the fibers we recovered (Fig. 11; $r=-0.8, p<0.001$ ).

There were strong correlations between receptive-field size and axon-arbor diameter in the coronal plane for both Type 1 and Type 2 axons (Fig. 12A). For Type 2 axons, the correlation was $0.81(p<0.005)$; for Type 1 fibers, it was $0.84(p<0.01)$. There was no significant relationship between receptive-field eccentricity and arbor size for Type 2 axons $(r=0.51, p=0.13$; Fig. 12B). However, the trend for Type 1 arbors to decrease in size with eccentricity did approach statistical significance $(r=$ $-0.79, p-0.06)$.

\section{Noncategorized fibers ( $\mathbf{N}=2$ )}

The single well-filled axon that did not have Type 1 or Type 2 physiological properties is shown in Figures 13 and 14. It is worth noting because its morphological characteristics were also quite distinct from those of either Type 1 or Type 2 fibers. This 


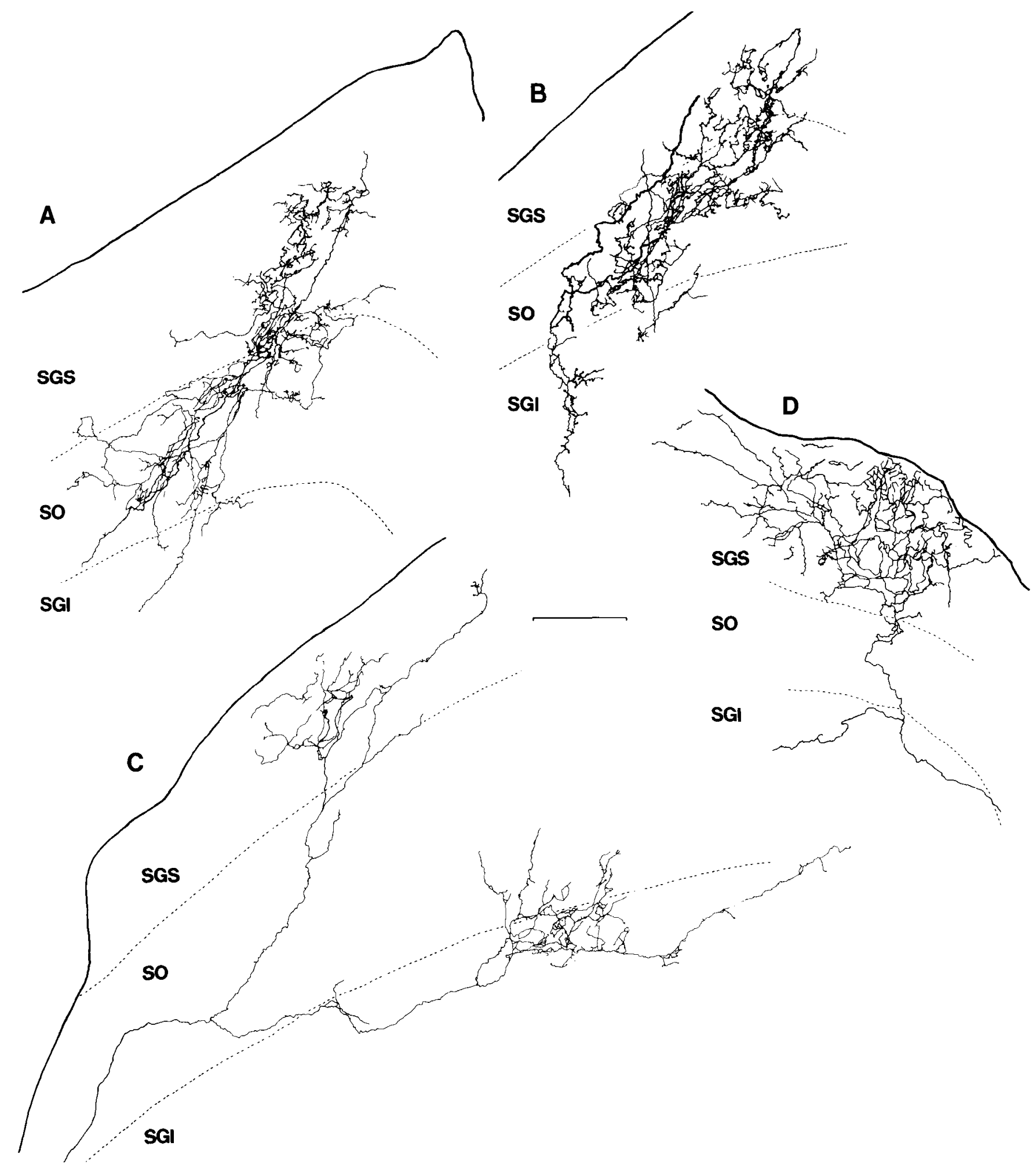

Figure 6. Reconstructions of 4 additional Type 1 axons. Note that all of these fibers have collaterals in the SGS, SO, and SGI. The fiber shown in $C$ was unique in that its terminal arbor had 2 distinct foci: one in the SGS and a second in the SGI and lowermost SO. Scale bar, $100 \mu \mathrm{m}$.

axon had a uniform on-off receptive field $8.1^{\circ}$ in diameter and a nonantagonistic or "silent" surround. It responded to only slowly moving stimuli $(<20 \% / \mathrm{sec})$ and gave no response to the drifting gratings. Its latency to $\mathrm{OX}$ stimulation was $4.2 \mathrm{msec}$. This axon entered the SC in the brachium (Figs. 13A, 14), then gave rise to a horizontally oriented arbor that had one focus just below the pial surface and another in the middle portion of the SGS. When it terminated, this axon also gave rise to both en passant and terminal boutons (Fig. 13B).

Another unclassifiable axon that we recovered gave a phasic on-response to receptive-field illumination, its receptive field measured $9.3^{\circ}$ in diameter, and it had no antagonistic surround. 

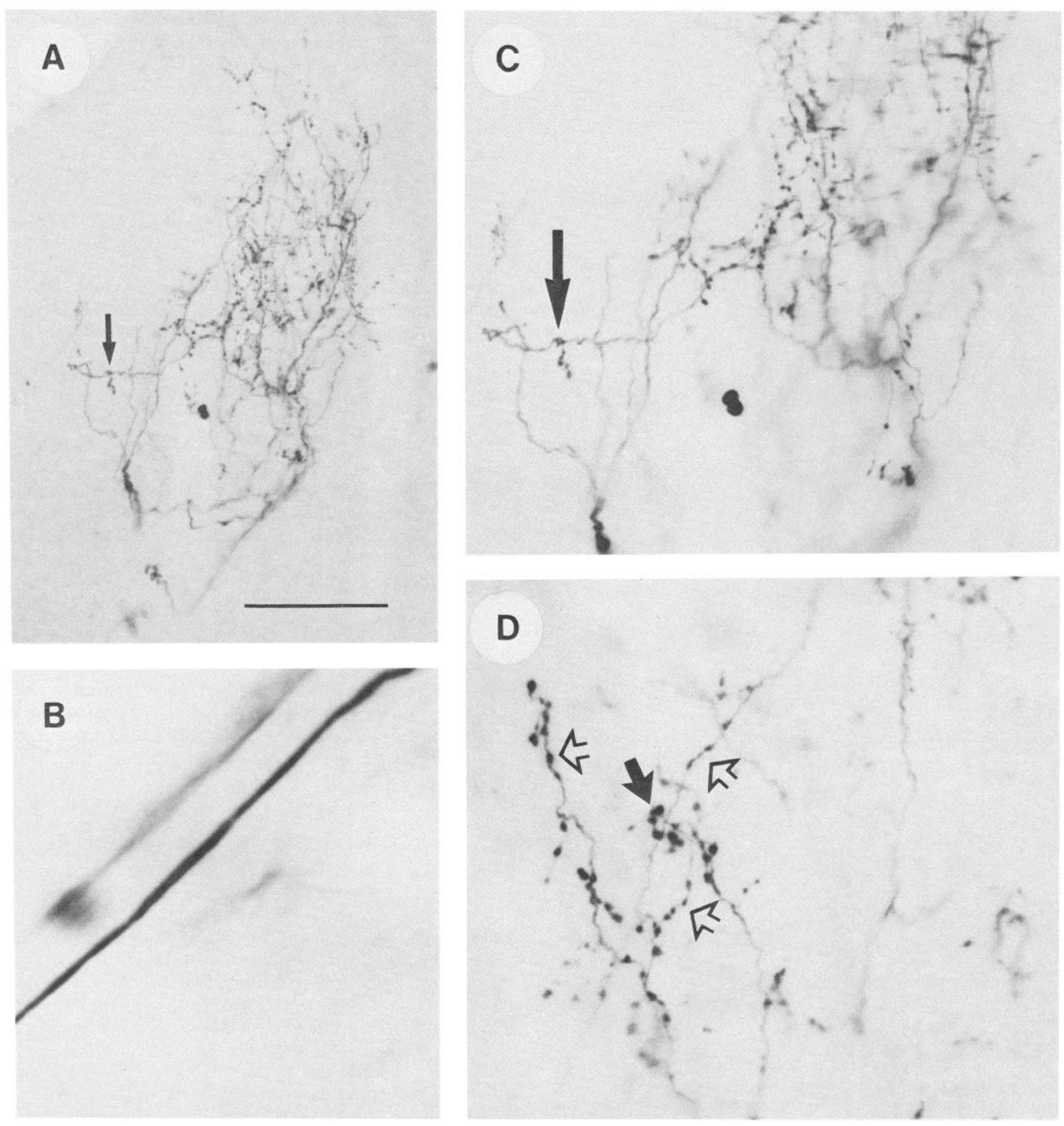

Figure 7. Photomicrographs showing portions of the Type 2 axon reconstructed in Figure $9 E$. A, Low-power photomicrograph that shows most of the terminal arbor for this axon. Note the elongation of the arbor along the dorsoventral axis. $B$, The axon in the brachium of the SC. $C$ and $D$, Portions of the terminal arbor at higher magnification. The arrow in $C$ points to the location that is also denoted by an arrow in $A$. The open arrows in $D$ point to boutons en passant, and the solid arrow points to a cluster of terminal boutons. Scale bar: $100 \mu \mathrm{m}$ for $A, 7 \mu \mathrm{m}$ for $B, 55 \mu \mathrm{m}$ for $C, 55 \mu \mathrm{m}$ for $D$.

It responded weakly to all stimuli and could not follow velocities $>20 \%$ sec. The latency of this axon's response to OX shock was $3.6 \mathrm{msec}$. This fiber was incompletely filled, but it was also horizontally oriented and branched near the pial surface.

\section{Discussion}

The laminar distribution of the retinal input to the colliculus. Intraaxonal injection of individual retinal axons in the hamster 


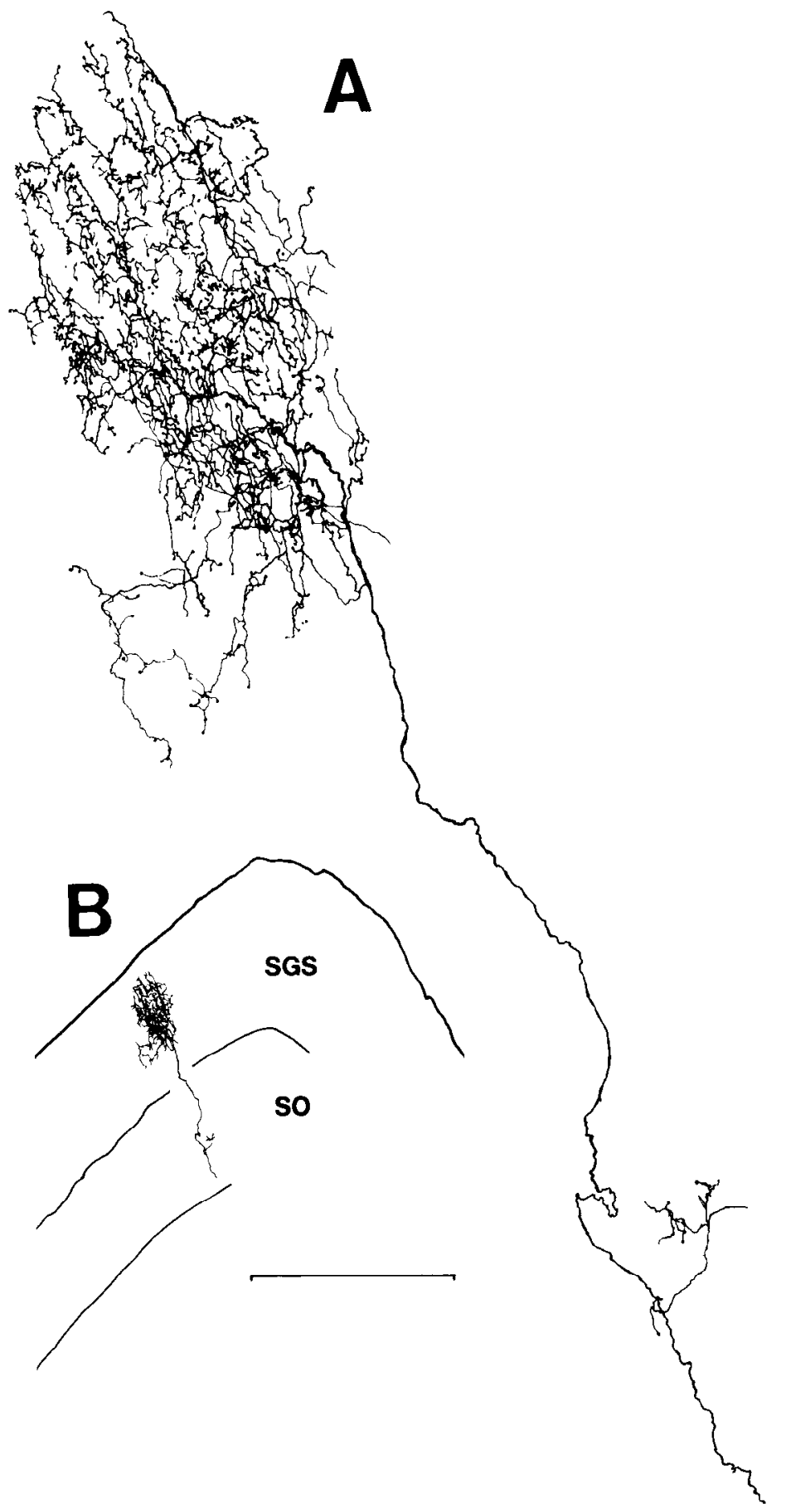

Figure 8. High- $(A)$ and low-power $(B)$ reconstructions of Type 2 axon. Note that, with the exception of a single small collateral in the SO, this arbor is completely restricted to the SGS. Scale bar: $100 \mu \mathrm{m}$ for $A, 500$ $\mu \mathrm{m}$ for $B$.

provided data that are in good accord with findings that have been obtained with less direct methods in other species. Both electrophysiological recordings (e.g., Hoffmann, 1973; McIlwain, 1978; Ogawa and Takahashi, 1981) and retrograde tracing with HRP (e.g., Itoh et al., 1981; Hofbauer and Dräger, 1985) have indicated that large retinal ganglion cells with rapidly conducting axons terminate in the deeper portion of the SGS and $\mathrm{SO}$, and that smaller ganglion cells with more slowly conducting axons terminate in the SZ and upper SGS. The Type 2 fibers we recovered terminated in the middle portion of the SGS, and the more rapidly conducting Type 1 axons terminated primarily in the lower SGS and SO. The 2 fibers that were neither Type 1 nor Type 2 had relatively slowly conducting axons and gave rise to terminal arbors in the uppermost part of the SGS.

The laminar distributions of different types of retinotectal axons fit very well with the results of an evoked-potential study carried out in the rat SC by Fukuda et al. (1978; see also Freeman and Singer, 1983, for comparable data from the cat). On the basis of their physiological results, Fukuda et al. (1978) identified 3 zones, N1-N3, in superficial laminae of the rat's SC. The most dorsal zone, N3, was in the uppermost SGS and received its input from slowly conducting retinal axons. The $\mathrm{N} l$ zone was located at the SGS-SO border, and it received input from the most rapidly conducting axons. The N2 zonc, located in the middle of the SGS, was somewhat harder to define on the basis of evoked-potential recordings, but it appeared to be innervated by retinal axons with intermediate conduction velocities.

Previous studies have also provided evidence that some retinal fibers project to the SC laminae ventral to the SO. Several early experiments that employed anterograde degeneration techniques illustrated small amounts of argyrophilia ventral to the SO (e.g., Laties and Sprague, 1966; Eichler and Moore, 1974). More recently, Beckstead and Frankfurter (1983) employed anterograde transport of HRP to demonstrate that retinal axons in the rat, cat, and monkey terminated in the SGI. Their result for the cat was anticipated by the electrophysiological study of Berson and McIlwain (1982), who showed that some tectopredorsal bundle cells in the SGI of this species received direct input from retinal $\mathrm{Y}$ axons. However, the fact that many decplayer cells, including tecto-predorsal bundle neurons, have dendritic branches in the SO and even in the SGS (Mooney et al., 1984; Moschovakis and Karabelas, 1985; Rhoades et al., 1987; Moschovakis et al., 1988) means that the cells recorded by Berson and Mcllwain (1982) could have received retinal synapses onto either superficial or deep-layer dendrites. Our results provide firm evidence that retinal axons with a distinct set of functional characteristics send axon collaterals ventral to the SO.

The morphology of individual retinotectal axons. There are no data from any species that can be directly compared with the results of the present study. As noted in the introductory remarks, Bowling and Michael (1980) illustrated the axon of one $\mathrm{Y}$ cell in the cat SC. However, in a later report (Bowling and Michael, 1984), they noted that almost all of the midbrain collaterals of this fiber were located in the pretectum.

Individual axons almost certainly of retinal origin have been labeled by Sachs and Schneider (1984), who placed very small deposits of HRP in the hamster optic tract. They identified 3 fiber types that were present after cortical lesions, but not after eye removals. Their U-type afferents had relatively thin axons, and arbors that were elongated in the dorsoventral axis in the upper $2 / 3$ of the SGS. These fibers (see Sachs and Schneider, 1984, their Figs. 3, 4) are almost certainly equivalent to our Type 2 axons. The L1 axons of Sachs and Schneider (1984) had thicker parent fibers, had more horizontally oriented arbors, and terminated in the lower SGS and SO. These fibers would appear to correspond to our Type 1 fibers, but it is important to note that Sachs and Schneider (1984) did not observe any collaterals from these axons in the intermediate layers.

There is one other point of agreement between our data and 

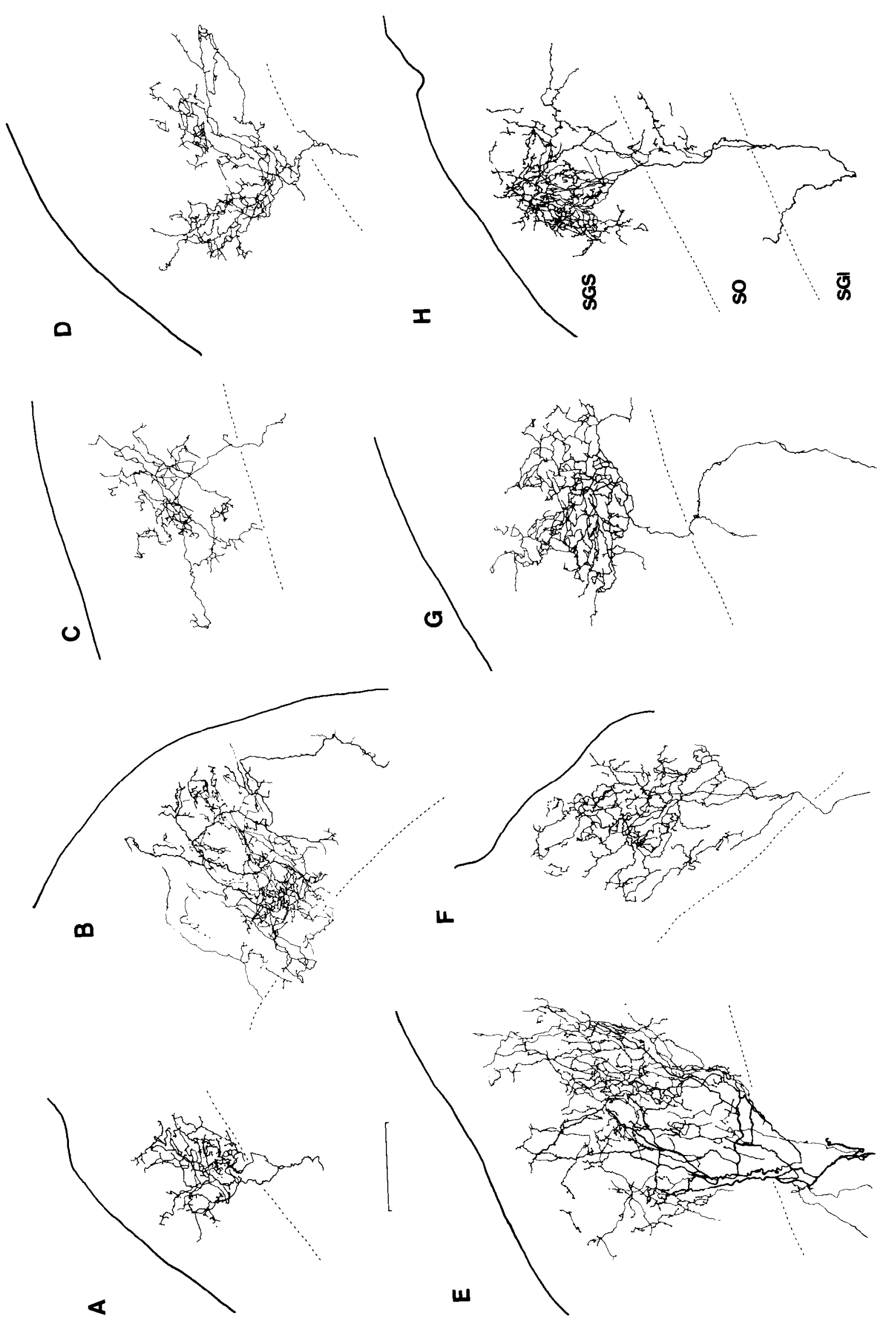


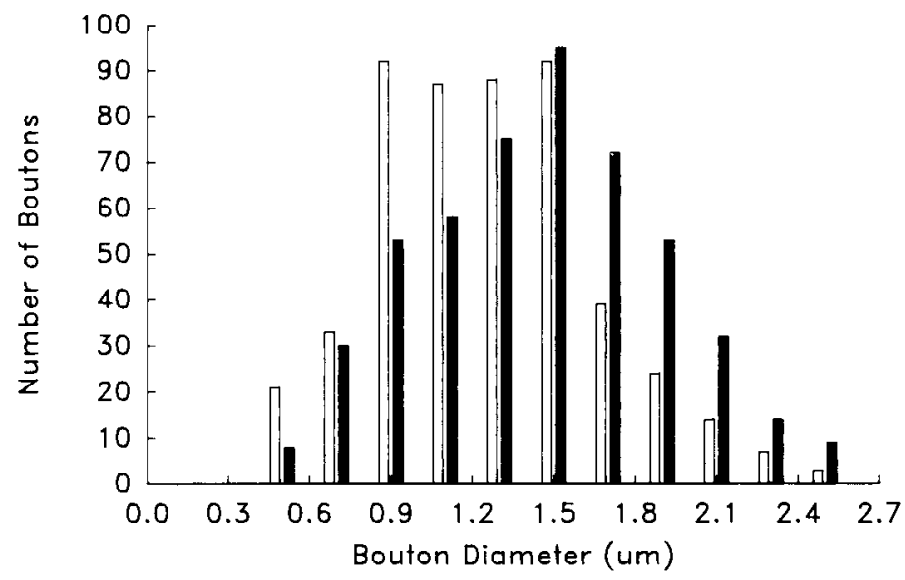

Figure 10. Distribution of average diameters ([long axis + short axis]/ 2) for 100 bouton-like swellings measured from each of 5 Type 1 fibers (solid bars) and 100 boutons measured from each of 5 Type 2 axons (open bars). The average for the boutons measured from Type 2 fibers was $1.13 \mu \mathrm{m}(\mathrm{SD}=0.40)$, and that for boutons measured from Typc 1 fibers was $1.32(\mathrm{SD}=0.44)$. There was no significant difference between the 2 distributions.

those of Sachs and Schneider (1984). They reported that $U$ fibers (probably our Type 2 axons) had arborizations that did not vary in size with their location in the colliculus. On the other hand, their L1 fibers (probably Type 1 axons) had large arbors in the region where the upper nasal visual field was represented and were much smaller in the part of the SC representing the lower temporal part of the visual field. The Type 2 axons we recovered, like the U fibers of Sachs and Schneider (1984), had arbor sizes that did not vary significantly with eccentricity. We also noted a nearly significant trend for the arbors of Type 1 axons to decrease in size with increasing eccentricity.

Relationship between classes of retinotectal axons in the hamster and other species. In rodents, it is likely that all classes of retinal ganglion cells project to the SC (Linden and Perry, 1983),

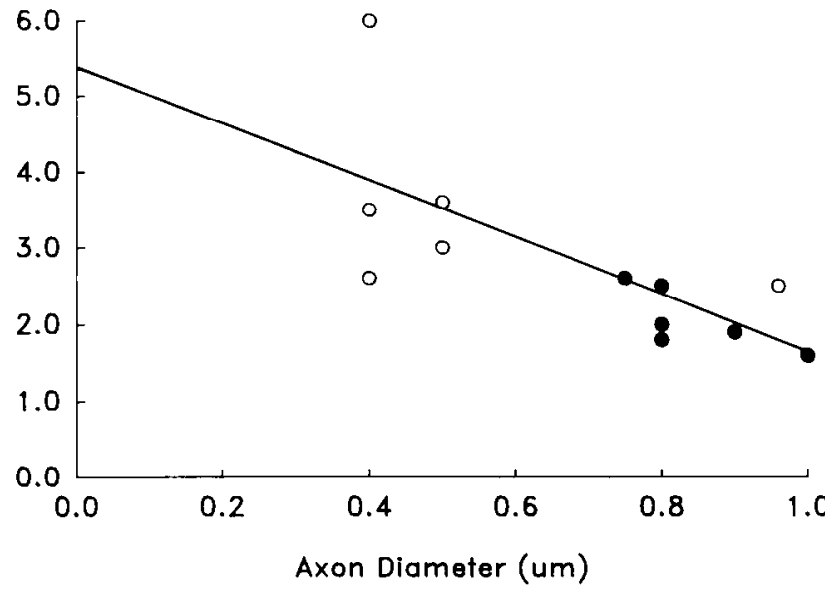

Figure 11. Scatterplot showing relationship between response latency and axon diameter for recovered Type 1 (solid circles) and Type 2 (open circles) retinotectal axons. The correlation between these 2 variables was $-0.80(p<0.001)$. Note that, with 1 exception, all recovered Type 1 axons had larger axon diameters and shorter conduction latencies to OX stimulation than Type 2 axons.

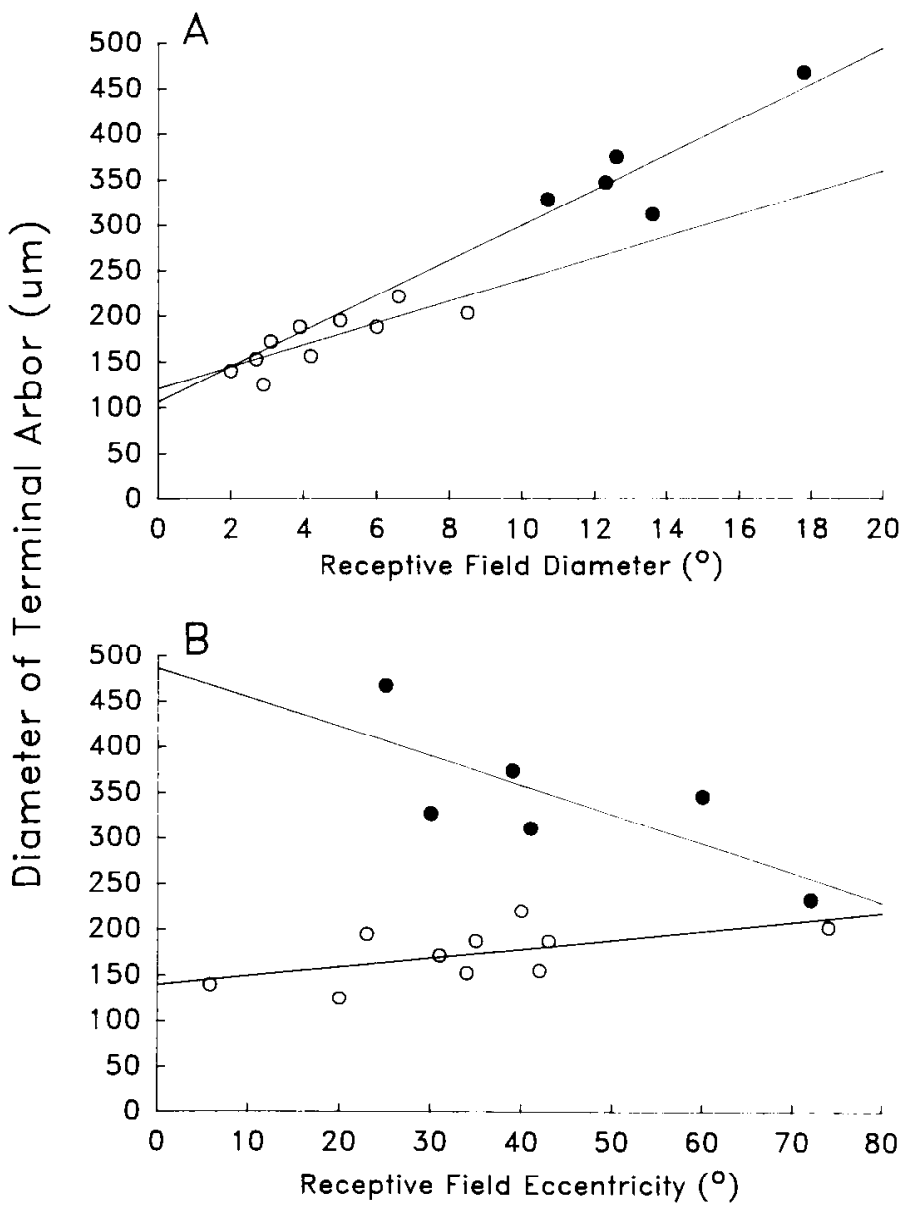

Figure 12. Relationship between terminal-arbor diameter and receptive-field diameter and eccentricity. $A$, The relationship between receptive field diameter and axon arbor diameter for Type 1 (solid circles) and Type 2 (open circles) axons. The correlation coefficient for the Type 1 axons was $0.84(p<0.05)$, and that for the Type 2 fibers was $0.81(p$ $<0.001)$. $B$, The relationship between the diameter of the terminal arbor and the eccentricity of the respective fiber's receptive field for these 2 types of retinotectal axons. There was no significant relationship between eccentricity and arbor size for Type 2 axons $(r=0.51, p=$ 0.13 ). However, the trend for Type 1 arbors to decrease in size with eccentricity did approach statistical significance $(r=-0.79, p=0.06)$.

and comparison of the data presented here with those provided by Rhoades and Chalupa (1979) indicate that we have probably failed to recover any of the most slowly conducting retinotectal fibers. It is reasonable to argue that the fibers we have classified as Type 1 correspond to $\mathrm{Y}$ axons. Their responses are quite similar to those of $Y$ cells recorded from the cat (Fukuda and Stone, 1974), and several investigators have shown that the rodent retina contains a class of ganglion cells that are quite similar to the $\alpha$ cells of the cat retina (Perry, 1979; Reese and Cowey, 1986; Peichl, 1989). Both Fukuda et al. (1988) and $\mathrm{Ni}$ and Dreher (1981) have demonstrated that such neurons can be retrogradely labeled from the rat $\mathrm{SC}$.

It is more difficult to relate our Type 2 axons to retinal ganglion cells that project to the cat SC. Some of the properties of our Type 2 fibers (linear spatial summation, smaller receptive fields, and sustained responses to flashed stimuli) are similar to those of X cells (Kratz et al., 1978). However, it has been argued that no $\beta$ cells (the morphological correlate of $X$ cells) are present in the rodent retina (Perry, 1979). Hale et al. (1979) have also 

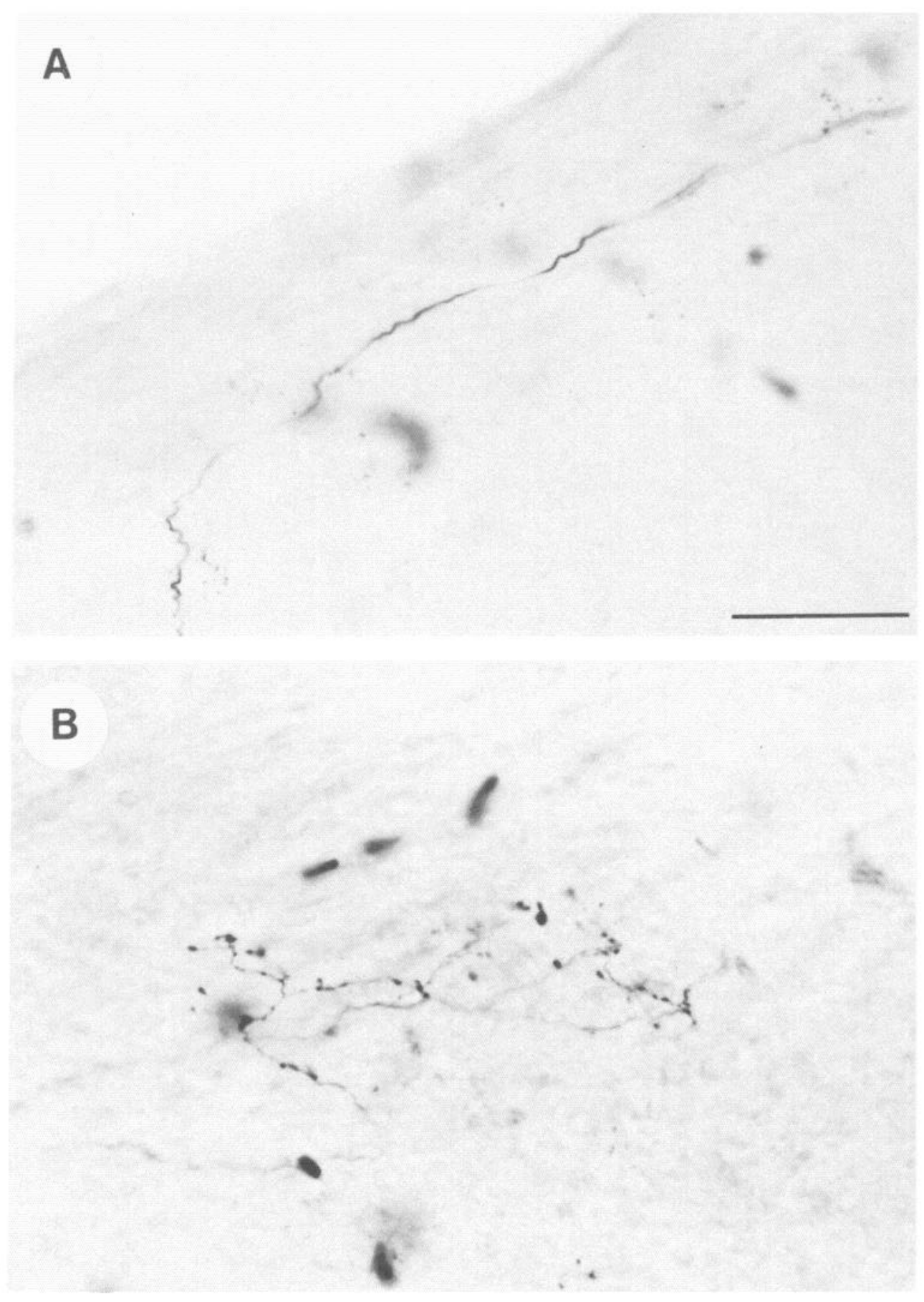

Figure 13. Photomicrographs showing portions of noncategorized axon reconstructed in Figure 14. $A$, The axon in the brachium of the SC. $B$, A portion of the terminal arbor in the upper SGS. Scale bar: $50 \mu \mathrm{m}$ for $A, 40 \mu \mathrm{m}$ for $B$. reported that only a small percentage of neurons in the rat lateral geniculate nucleus have $\mathrm{X}$-like receptive fields (but see also Lennie and Perry, 1981). It is possible that our Type 2 fibers arose from tonic $\mathrm{W}$ cells. Such ganglion cells have coarser axons and somewhat smaller receptive fields than phasic $\mathrm{W}$ cells, and they can also exhibit linear spatial summation (Stanford, 1987). Distinction between these 2 possibilities will only be possible after accomplishment of a complete functional classification of ganglion cell types in the rodent retina.

Relationship between organization of retinocollicular input and the responses of $S C$ cells. At present, it is unclear how the segregation of different functional classes of retinal afferents influ- ences the physiological characteristics of SC neurons. In the hamster, none of the properties of SC neurons, with the exception of receptive-field size, change as a function of depth in the SC (e.g., Rhoades and Chalupa, 1979). While this correlation between receptive-field properties and depth in the SC might be explained by the larger receptive fields of the $\mathrm{Y}$ axons that innervate the deeper portion of the superficial layers, it might also be the result of the larger dendritic arbors of, and greater convergence onto, neurons in this portion of the SC (e.g., Mooney et al., 1985, 1988a, b). Rhoades and Chalupa (1979) recorded from SC neurons in hamsters and noted no strong relationship between the depth of recorded cells and the conduction 


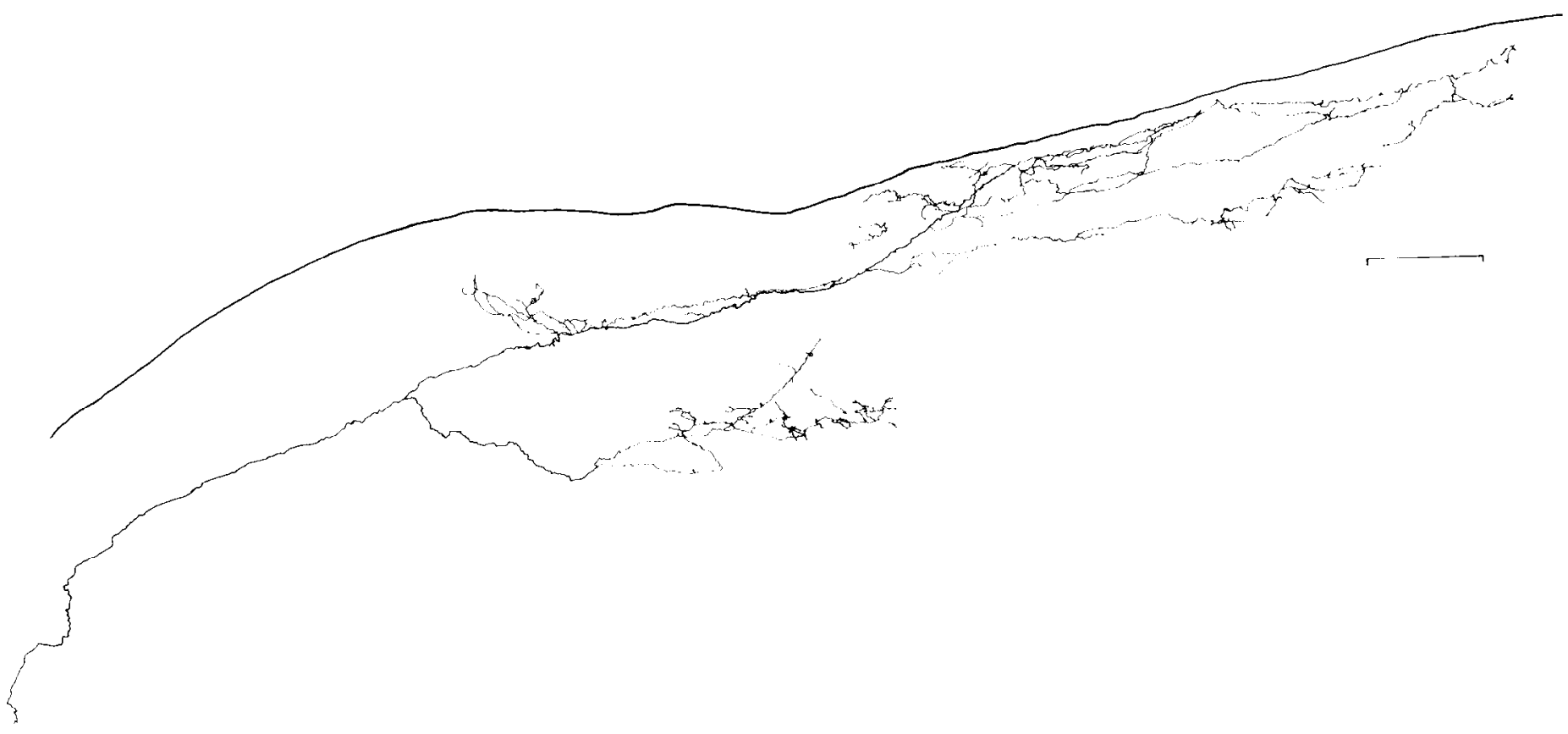

Figure 14. Reconstruction of the noncategorized axon depicted in Figure 13. The calibration is $100 \mu \mathrm{m}$. Note the elongation of the axon arbor along the mediolateral axis and that most of the arborization is just below the pial surface of the colliculus.

velocity of their retinal input. That study did identify 1 relationship between input and receptive field type: SC cells that were strongly directionally selective (i.e., had a null direction; Barlow and Levick, 1965) tended to be innervated by relatively slowly conducting axons (see Rhoades and Chalupa, 1979, their Fig. $7 A$ ). Hoffmann (1973) has also observed that directionally selective cells in the cat SC are more likely to be driven by the slow direct $\mathrm{W}$ pathway than the more rapidly conducting direct Y projection.

The data relating the laminar organization of retinal input and the response properties of SC cells in the cat are considerably more clear-cut than those for the hamster. In this species, cells driven by rapidly conducting $Y$ axons are located only in the ventral portion of the superficial layers and in the upper part of the deep layers, while neurons activated by more slowly conducting $W$ axons are located in the upper portion of the superficial gray layer (Hoffmann, 1973; Ogawa and Takahashi, 1981; Berson and McIlwain, 1982; Berson, 1988). Most recently, Mize and Hockfield (1989) have demonstrated that the monoclonal antibody Cat-301, which preferentially labels $\mathrm{Y}$ cells in several visual structures (e.g., Sur et al., 1984, 1988), stains many neurons in the deep portion of the SGS, the SO, and all the deep layers, but almost no cells in the upper SGS of the cat SC.

\section{References}

Barlow HB, Levick WR (1965) The mechanism of directionally selective units in the rabbit's retina. J Physiol (Lond) 178:447-504.

Beckstead RM, Frankfurter A (1983) A direct projection from the retina to the intermediate gray layer of the superior colliculus demonstratcd by anterograde transport of horseradish peroxidase in monkey, cat and rat. Exp Brain Res 52:261-268.

Berson DM (1988) Convergence of retinal W-cell and corticotectal input to cells of the cat superior colliculus. J Neurophysiol 60:18611873.

Berson DM, McIlwain JT (1982) Retinal Y-cell activation of deeplayer cells in superior colliculus of the cat. J Neurophysiol 47:700714.
Bowling DB, Michael CR (1980) Projections of single physiologically characterized optic tract fibers in cat. Nature 286:899-902.

Bowling DB, Michael CR (1984) Terminal patterns of single physiologically characterized optic tract fibers in the cat's lateral geniculate nucleus. J Neurosci 4:198-216.

Bunt AH, Hendrickson AE, Lund JS, Lund RD, Fuchs AF (1975) Monkey retinal ganglion cells: morphological analysis and tracing of axonal projections with a consideration of the peroxidase technique. J Comp Neurol 164:265-286.

Chalupa LM, Thompson I (1980) Retinal ganglion cell projections to the superior colliculus of the hamster demonstrated by the horseradish peroxidase technique. Neurosci Lett 19:13-19.

Cleland BG, Levick WR (1974a) Brisk and sluggish concentrically organized ganglion cells in the cat's retina. J Physiol (Lond) 240:421456.

Cleland BG, Levick WR (1974b) Properties of rarely encountered types of ganglion cells in the cat's retina and an overall classification. J Physiol (Lond) 240:457-492.

Cleland BG, Levick WR (1975) The nature of the "induced" discharges of cat retinal ganglion cells. J Physiol (Lond) 244:60P.

Cleland BG, Dubin MW, Levick WR (1971) Sustained and transient neurons in the cat's retina and lateral geniculate nucleus. J Physiol (Lond) 217:473-496.

Cleland BG, Levick WR, Sanderson KJ (1973) Properties of sustained and transient cells in the cat's retina. J Physiol (Lond) 288:649-680.

Eichler VB, Moore RY (1974) The primary and accessory optic systems in the golden hamster (Mesocricetus auratus). Acta Anat 89; 359-371.

Enroth-Cugell C, Robson JG (1966) The contrast sensitivity of retinal ganglion cells of the cat. J Physiol (Lond) 187:517-552.

Fernald R, Chase R (1971) An improved method for plotting retinal landmarks and focusing the eyes. Vision Res 11:95-96.

Freeman B, Singer W (1983) Direct and indirect visual inputs to superficial layers of cat superior colliculus: a current source-density analysis of electrically evoked potentials. J Neurophysiol 49:10751091.

Freminet A, Bursaux E, Poyart C (1972) Mesure de la vitesse de renouvellement du lactate chez le rat par perfusion de ${ }^{14} \mathrm{C}$-U-(L)lactate's. Pfleugers Arch 334:293-302.

Fukuda Y, Stone J (1974) Retinal distribution and central projections of $Y_{-}, X_{-}$, and W-cells of the cat's retina. J Neurophysiol 37:749772.

Fukuda Y, Suzuki DA, Iwama K (1978) Characteristics of optic nerve 
innervation in the rat superior colliculus as revealed by field potential analysis. Jpn I Physiol 28:347-365.

Fukuda Y, Morigiwa K, Tauchi M (1988) Morphology of alpha ganglion cells in the albino rat retina. Biomed Res 9:139-142

Hale PT. Sefton AJ. Dreher B (1979) A correlation of receptive field properties with conduction velocity of cells in the rat's retino-geniculo-cortical pathway. Exp Brain Res 35:425-442.

Hamos JE, Van Horn S, Raczkowski D, Sherman SM (1987) Synaptic circuits involving an individual retinogeniculate axon in the cat. J Comp Neurol 259:165-192.

Hochstein S. Shapley RM (1976) Quantitative analysis of retinal ganglion cell classifications. J Physiol (Lond) 262:237-264.

Hofbauer A. Dräger UC (1985) Depth segregation of retinal ganglion cells projecting to mouse superior colliculus. J Comp Neurol 234 : $465-474$.

Hoffmann K-P (1973) Conduction velocity in pathways from retina to superior colliculus in the cat: correlation with receptive field propcrtics. I Neurophysiol 36:409-424.

Itoh K. Conley M. Diamond IT (1981) Different distributions of large and small retinal ganglion cells in the cat after HRP injections of single layers of the lateral geniculate body and the superior colliculus. Brain Res 207:147-152.

Kelly JP, (iilbert (D) (1975) The projection of different morphological types of ganglion cells in the cat retina. J Comp Neurol 163:65-80.

Krat KF. Webb SV. Sherman SM (1978) Electrophysiological classification of $\mathrm{X}$ - and $\mathrm{Y}$-cells in the cat's lateral geniculate nucleus. Vision Res 18:1261-1264.

Laties AM. Sprague JM (1966) The projection of optic fibers to the visual centers in the cat. J Comp Neurol 127:35-70.

Lennie P. Perry VH (1981) Spatial contrast sensitivity of cells in the lateral geniculate nucleus of the rat. J Physiol (Lond) 315:69-79.

Leventhal A(j, Rodieck RW. Dreher B (1981) Retinal ganglion cell classes in the old word monkey: morphology and central projections. Science 213:1139-1142.

Leventhal AGi, Rodieck RW, Dreher B (1985) Central projections of cat retinal ganglion cells. J Comp Neurol 237:216-226.

Linden R, Perry VH (1983) Massive retinotectal projection in rats. Brain Res 272:145-149.

Magalhaes-Castro HH. Murata LA, Magalhaes-Castro B (1976) Cat retinal ganglion cells projecting to the superior colliculus as shown by the horseradish peroxidase method. Exp Brain Res 25:541-549.

Marrocco RT (1978) Conduction velocities of afferent input to superior colliculus in normal and decorticate monkeys. Brain Res 140: $155-158$

McIlwain JT (1978) Cat superior colliculus: extracellular potentials related to $W$-cell synaptic actions. J Neurophysiol 41:1343-1358.

Michacl ( (1988) Retinal afferent arborization patterns, dendritic field orientations, and the segregation of function in the lateral geniculate nucleus of the monkey. Proc Nat Acad Sci USA 85:4914-4918.

Mize RR, Hockfield S (1989) Cat-301 antibody selectively labels neurons in the $Y$-innervated laminae of the cat superior colliculus. Visual Neurosci $3: 433-443$.

Mooney RD. Klein BG. Jacquin MF, Rhoades RW (1984) Dendrites of deep layer. somatosensory superior collicular neurons extend into the superficial laminae. Brain Res 324:361-365.

Mooney RI), Klein BG, Rhoades RW (1985) Correlations between the structural and functional characteristics of neurons in the superficial laminae and the hamster's superior colliculus. J Neurosci 5: 2989-3009.

Mooncy RD. Nikoletseas MM, Rhoades RW (1987) Transection of the infraorbital nerve in newborn hamsters alters the somatosensory but not the visual representation in the superior colliculus. J Comp Neurol 266:27-44.

Mooney RI). Nikoletseas MM, Ruiz SA. Rhoades RW (1988a) Receptive-field properties and morphological characteristics of the superior collicular neurons that project to the lateral posterior and dorsal lateral geniculate nuclei in the hamster. J Neurophysiol 59:13331351.

Mooney RI). Nikoletseas MM, Hess PR, Allen Z, Lewin AC, Rhoades RW (1988b) The projection from the superficial to the deep layers of the superior colliculus: an intracellular horseradish peroxidase injection study in the hamster. J Neurosci 8:1384-1399.

Moschovakis AK. Karabelas AB (1985) Observations on the somatodendritic morphology and axonal trajectory of intracellularly HRPlabeled efferent neurons located in the decper layers of the superior colliculus of the cat. J Comp Neurol 239:276-308.

Moschovakis AK, Karabelas AB, Highstein SM (1988) Structure-function relationships in the primate superior colliculus. I. Morphological classification of efferent neurons. J Neurophysiol 6():232-262.

Ni SYK. Dreher B (1981) Morphology of rat retinal ganglion cells projection to the thalamus and midbrain. Proc Aust Physiol Pharmacol Soc 12:97.

Ogawa T. Takahashi Y (1981) Retinotectal connectivities within the superficial layers of the cat's superior colliculus. Brain Res 217:1-11.

Peichl I (1989) Alpha and delta ganglion cellsin the rat retina J comp Neurol 286:120-139.

Perry VH (1979) The ganglion cell layer of the retina of the rat: a Golgi study. Proc R Soc Lond [Biol] 204:363-375.

Perry VH, Cowey A (1984) Retinal ganglion cells that project to the superior colliculus and pretectum in the macaque monkey. Neuroscience 12:1125-1137.

Powers MK, Green DG (1978) Single retinal ganglion cell responses in the dark-reared rat: grating acuity, contrast sensitivity, and defocusing. Vision Res 18:1533-1539.

Reese BE, Cowey A (1986) Large retinal ganglion cells in the rat: their distribution and laterality of projection. Exp Brain Res 0 1:375-385.

Rhoades RW. Chalupa LM (1979) Conduction velocity distribution of the retinal input to the hamster's superior colliculus and a correlation with receptive field characteristics. J Comp Neurol 184:?43264.

Rhoades RW, Mooney RD. Klein B(i, Jacquin MF, S/crepanik AM. Chiaia NL (1987) The structural and functional characteristics of tectospinal neurons in the golden hamster. J Comp Neurol 255:451465 .

Roe AW. Garraghty PE. Sur M (1989) Terminal arbors of single oncenter and off-center $X$ and $Y$ retinal ganglion cell axons within the ferret's lateral geniculate nucleus. I Comp Neurol 288:208-242.

Sachs (iM. Schneider GE (1984) The morphology of opte tract axons arborizing in the superior colliculus of the hamster. I (omp Neurol $230: 155-167$

Schiller PH. Malpeli JG (1977) Properties and tectal projections of monkey retinal ganglion cells. J Neurophysiol 40:428-445.

Semba K. Masarachia P. Malamed S. Jacquin M. Harris S. Yang (; Egger MD (1983) An electron microscopic study of primary afferent terminals from slowly adapting type I receptors in the cat. I comp Neurol 221:466-481.

Stanford LR (1987) W-cells in the cat retina: correlated morphological and physiological evidence for two distinct classes. I Neurophysiol $57: 218-244$.

Stone J. Fukuda Y (1974) Properties of cat retinal ganglion cells: a comparison of W-cells with X-and Y-cells. I Neurophysiol 37:722748 .

Sur M. Sherman SM (1982) Retinogeniculate terminations in cats morphological differences between physiologically identified $X$-and $Y$-cell axons. Science 21 8:389-391.

Sur M. Hockfield S, MacAvoy M. Garraghty P. Krityer M. MKay R (1984) A monoclonal antibndy that may identify Y rells in the cat lateral geniculate nucleus. Soc Neurosci Abst 10:297.

Sur M, Esguerra M, Garraghty PE. Kritzer MF. Shernan SM (1987) Morphology of physiologically identified retinogeniculate $X$ - and $Y$-axons in the cat. J Neurophysiol 58:1-32.

Sur M, Frost DO, Hockfield $S$ (1988) Expression of a surface-associated antigen on $Y$ cells in the cat lateral geniculate nucleus is regulated by visual experience. J Neurosci 8:874-88?

Tiao YC, Blakemore C (1976) Regional specialization in the golden hamster's retina. J Comp Neurol 168:439-458.

Wäsle H, Illing R-B (1980) The retinal projection to the superior colliculus in the cat: a quantitative study with HRP. J Comp Neurol 190:333-356. 